\title{
Feeding by the mixotrophic red-tide dinoflagellate Gonyaulax polygramma: mechanisms, prey species, effects of prey concentration, and grazing impact
}

\author{
Hae Jin Jeong ${ }^{1, *}$, Yeong Du Yoo ${ }^{2}$, Kyeong Ah Seong ${ }^{3}$, Jong Hyeok Kim ${ }^{4}$, \\ Jae Yeon Park ${ }^{1}$, Sanghee Kim ${ }^{5}$, Seung Hyeon Lee ${ }^{1}$, Jeong Hyun Ha ${ }^{1}$, Won Ho Yih ${ }^{4}$ \\ ${ }^{1}$ School of Earth and Environmental Sciences, College of Natural Sciences, Seoul National University, Seoul 151-747, Korea \\ ${ }^{2}$ Saemankeum Environmental Research Center, Kunsan National University, Kunsan 573-701, Korea \\ ${ }^{3}$ MarineBio Co., Myrongdong San 68, Kunsan 573-701, Korea \\ ${ }^{4}$ Department of Oceanography, College of Ocean Science and Technology, Kunsan National University, Kunsan 573-701, Korea \\ ${ }^{5}$ School of Biological Science, College of Natural Sciences, Seoul National University, Seoul 151-747, Korea
}

\begin{abstract}
The red-tide dinoflagellate Gonyaulax polygramma (GenBank accession number = AJ833631), previously known as an exclusively autotrophic dinoflagellate, has been found to be a mixotrophic species. We investigated feeding mechanisms, types of prey species, and the effects of prey concentration on the growth and ingestion rates of G. polygramma when feeding on an unidentified cryptophyte species (equivalent spherical diameter, ESD $=5.6 \mu \mathrm{m}$ ). We also calculated grazing coefficients by combining field data on abundances of G. polygramma and co-occurring cryptophytes with laboratory data on ingestion rates obtained in the present study. Among the phytoplankton prey offered, G. polygramma ingested small phytoplankton species with ESD $\leq 17 \mu \mathrm{m}$, but did not feed on large phytoplankton species with ESD $>22 \mu \mathrm{m}$. G. polygramma fed on prey cells by engulfing them through the apical horn, a previously unknown mechanism, as well as through the sulcus. The feeding mechanism of $G$. polygramma on phytoplankton mainly depended on the prey species. Specific growth rates of G. polygramma on a cryptophyte increased with increasing mean prey concentration, with saturation occurring at a mean prey concentration of approximately $600 \mathrm{ng} \mathrm{C} \mathrm{ml}^{-1}$. The maximum specific (mixotrophic) growth rate of G. polygramma on a cryptophyte was $0.278 \mathrm{~d}^{-1}$, under a 14:10 h light:dark cycle of $50 \mu \mathrm{E} \mathrm{m}^{-2} \mathrm{~s}^{-1}$, while its (phototrophic) growth rate under the same light conditions without added prey was $0.186 \mathrm{~d}^{-1}$. Its maximum ingestion and clearance rates were $0.18 \mathrm{ng} \mathrm{C}$ grazer ${ }^{-1} \mathrm{~d}^{-1}$ (10.6 cells grazer ${ }^{-1} \mathrm{~d}^{-1}$ ) and $0.18 \mu$ grazer $^{-1} \mathrm{~h}^{-1}$, respectively. The grazing coefficients of G. polygramma on cryptophytes were up to $0.479 \mathrm{~h}^{-1}$. The results of the present study suggest that $G$. polygramma can have a considerable grazing impact on cryptophyte populations.
\end{abstract}

KEY WORDS: Feeding process $\cdot$ Harmful algal bloom · Ingestion · Marine $\cdot$ Protist $\cdot$ Red tide

\section{INTRODUCTION}

Dense blooms of microalgae or so-called red tides can upset the balance of food webs and cause largescale mortalities of finfish and shellfish (ECOHAB 1995). They have frequently caused great losses to the aquaculture and tourist industries of many countries. Fully understanding the ecology and physiology of red-tide organisms and thus the mechanisms for the outbreak, persistence, and decline of red tides is a primary concern for scientists in related fields.

Recently, red-tide dinoflagellates, previously known as phototrophic dinoflagellates, have been revealed to be mixotrophic (Bockstahler \& Coats 1993, Jacobson \& Anderson 1996, Granéli et al. 1997, Stoecker et al. 1997, Smalley et al. 1999, Stoecker 1999, Skovgaard 2000, Jeong et al. 2004). The thecate dinoflagellate Gonyaulax polygramma has caused red tides in the 
coastal waters off many countries such as Korea, Japan, China, Hong Kong, USA, Mexico, Belize, South Africa, and Algeria (Grindley \& Taylor 1962, Kamykowski 1980, Lam \& Yip 1990, Lin et al. 1993, Koizumi et al. 1996, 2001, Faust 2000, Garate-Lizarraga et al. 2001, Ounissi \& Retima 2001). Red tides dominated by G. polygramma have sometimes caused the mass mortality of finfish and shellfish from anoxia (Grindley \& Taylor 1962, Koizumi et al. 1996, Garate-Lizarraga et al. 2001). Recently, we found food vacuoles inside $G$. polygramma, which had previously been known as an exclusively autotrophic dinoflagellate. This observation implies that G. polygramma can be mixotrophic. If it is confirmed that G. polygramma is mixotrophic, the models for predicting the outbreak, persistence, and decline of red tides dominated by this species and the related management strategies should be adjusted to reflect this fact. However, there have been no reports on the feeding mechanisms, prey species, and growth and grazing rates of G. polygramma on its prey yet. To understand the dynamics of red tides dominated by $G$. polygramma, the prey species and the growth and grazing rates of $G$. polygramma should be explored.

We established a monoclonal culture of Gonyaulax polygramma and observed its feeding behavior in order to explore feeding mechanisms and determine prey species; feeding frequency was measured when diverse phytoplankton species were provided. Experiments were conducted to determine the effects of prey concentration on the growth and ingestion rates of $G$. polygramma when feeding on an unidentified cryptophyte species (equivalent spherical diameter, ESD = $5.6 \mu \mathrm{m})$. We also estimated grazing coefficients attributable to G. polygramma on co-occurring cryptophytes using our data for ingestion rates obtained from the laboratory experiments and the abundances of predator and prey in the field. The results of the present study provide a basis for understanding the feeding mechanisms of G. polygramma, the interactions between $G$. polygramma and co-occurring phytoplankton, and the dynamics of red tides dominated by G. polygramma.

\section{MATERIALS AND METHODS}

Preparation of experimental organisms. Phytoplankton species were grown at $20^{\circ} \mathrm{C}$ in enriched $\mathrm{f} / 2$ seawater media (Guillard \& Ryther 1962) without silicate, under continuous illumination of $50 \mu \mathrm{E} \mathrm{m} \mathrm{m}^{-2} \mathrm{~s}^{-1}$ provided by cool white fluorescent lights (see Table 1). Mean ESD \pm standard deviation from the mean was measured by an electronic particle counter (Coulter Multisizer II, Coulter Corporation).

For the isolation and culture of Gonyaulax polygramma (GPSMK0209, GenBank accession number =
AJ833631), plankton samples collected with a $40 \mathrm{~cm}$ diameter, $25 \mu \mathrm{m}$ mesh plankton net were taken from coastal waters off Saemankeum, Korea, during September 2002, when the water temperature and salinity were $24.4^{\circ} \mathrm{C}$ and $29.3 \mathrm{psu}$, respectively. The samples were screened gently through a $154 \mu \mathrm{m}$ Nitex mesh and placed in 11 polycarbonate (PC) bottles. Fifty $\mathrm{ml}$ of $\mathrm{f} / 2$ media were added as food. The bottles were placed on shelves and incubated at $20^{\circ} \mathrm{C}$ under continuous illumination of $50 \mu \mathrm{E} \mathrm{m} \mathrm{m}^{-2} \mathrm{~s}^{-1}$ of cool white fluorescent light. Three days later, aliquots of the enriched water were transferred to 6 -well tissue culture plates and a monoclonal culture was established by 2 serial singlecell isolations. Once dense cultures of G. polygramma were obtained, they were transferred to 21 PC bottles containing ca. $500 \mathrm{ml}$ of fresh $\mathrm{f} / 2$ seawater media (final culture volume = ca. 1 l) every $2 \mathrm{wk}$. This strain produces bioluminescence.

Prey species. Expt 1 was designed to investigate whether or not Gonyaulax polygramma was able to feed on each target phytoplankton species when unialgal diets of diverse phytoplankton species were provided (Table 1). The initial concentrations of each phytoplankton species offered were similar in terms of carbon biomass. To confirm no ingestion by G. polygramma on some phytoplankton species, additional higher prey concentrations were provided.

A dense culture of Gonyaulax polygramma maintained in f/2 media and growing photosynthetically in exponential growth phase on shelves and incubated under the continuous illumination of $50 \mu \mathrm{E} \mathrm{m} \mathrm{m}^{-2} \mathrm{~s}^{-1}$ was transferred to a 11 PC bottle containing freshly filtered seawater. Three $1 \mathrm{ml}$ aliquots were then removed from the bottle and examined using a compound microscope to determine G. polygramma concentration.

In this experiment, the initial concentrations of Gonyaulax polygramma and each target phytoplankton species were established using an autopipette to deliver a predetermined volume of culture with a known cell density to the experimental bottles. Triplicate $80 \mathrm{ml}$ PC bottles (mixtures of G. polygramma and phytoplankton) and duplicate predator control bottles (containing G. polygramma only) were set up for each target phytoplankton species. The bottles were filled to capacity with freshly filtered seawater, capped, and then placed on a vertically rotating plate at $0.9 \mathrm{rpm}$ and incubated at $20^{\circ} \mathrm{C}$ under the continuous illumination of $50 \mu \mathrm{E} \mathrm{m} \mathrm{m}^{-2} \mathrm{~s}^{-1}$ of cool white fluorescent light. After $6 \mathrm{~h}$ incubation, a $5 \mathrm{ml}$ aliquot was removed from each bottle and transferred into a $10 \mathrm{ml}$ bottle. Two $0.1 \mathrm{ml}$ aliquots were placed on slides and then cover-glasses were added. Under these conditions, G. polygramma cells were alive, but almost motionless. The protoplasms of $>200$ G. polygramma cells were carefully examined with a com- 
pound microscope and/or an epifluorescent microscope at a magnification of 100 to 400 to determine whether or not G. polygramma was able to feed on the target prey species.

Feeding frequency. Expt 2 was designed to investigate the effects of prey species on the feeding frequency (FF) of Gonyaulax polygramma. FF is the proportion of G. polygramma cells that feed, as determined by the presence of ingested prey, and was calculated as the percentage of G. polygramma containing 1 or more target prey cells. FFs of G. polygramma on Isochrysis galbana, a cryptophyte, Amphidinium carterae, Heterosigma akashiwo, Heterocapsa triquetra, Prorocentrum minimum, and Scrippsiella sp., which had been revealed to be engulfed by G. polygramma in Expt 1, were measured. The initial concentrations of predator and prey were the same as in Expt 1 (Table 1).

Expt 2 was set up in the same way as Expt 1. After 10,30 , and $60 \mathrm{~min}$ incubation, a $5 \mathrm{ml}$ aliquot was removed from each bottle and transferred into a $10 \mathrm{ml}$ bottle. Two $0.1 \mathrm{ml}$ aliquots were placed on slides and then cover-glasses were added. The protoplasms of $>200$ G. polygramma cells were carefully examined with a compound microscope at a magnification of 100 to 400 and the numbers of G. polygramma with and without ingested prey were determined.

Feeding mechanisms. Expts 3 and 4 were designed to investigate the feeding mechanisms of Gonyaulax polygramma on a cryptophyte, Amphidinium carterae, Heterosigma akashiwo, Heterocapsa triquetra, Prorocentrum minimum, and Scrippsiella sp. Isochrysis galbana was too small for the feeding process to be observed. The initial concentrations of predator and prey were the same as in Expt 1.

In Expt 3, the initial concentrations of Gonyaulax polygramma and the target phytoplankton species were established using an autopipette to deliver a predetermined volume of culture with a known cell density to the experimental bottles. One $80 \mathrm{ml} \mathrm{PC}$ bottle (mixtures of G. polygramma and phytoplankton) was set up for each target phytoplankton species. The bottle was filled to capacity with freshly filtered seawater, capped, and then well mixed. After 1 min incubation, a $1 \mathrm{ml}$ aliquot was removed from the bottle and transferred into a $1 \mathrm{ml}$ Sedgwick-Rafter counting chamber. By monitoring the behavior of $>60$ unfed G. polygramma cells for each target prey species under a compound microscope at a magnification of 100 to 400 , the frequency of engulfment through the apical horn and the sulcus of the predator was measured. All feeding processes between a prey cell being captured and engulfed by each predator were observed. A series of pictures showing the feeding process of a G. polygramma cell was taken using a video analyzing system
(Toshiba IK-642F) on a compound microscope at a magnification of 100 to 400 .

In Expt 4, the time for a prey cell to be completely engulfed through the apical horn of Gonyaulax polygramma after the prey cell was contacted by the predator (i.e. handling time) was compared to that through the sulcus of the predator. We selected Amphidinium carterae as a test organism because the frequency of engulfment through the apical horn of the predator on this prey was similar to that through the sulcus in Expt 3.

Expt 4 was set up in the same way as Expt 3. After $1 \mathrm{~min}$ incubation, a $1 \mathrm{ml}$ aliquot was removed from the bottle and transferred into a $1 \mathrm{ml}$ Sedgwick-Rafter counting chamber. By monitoring the behavior of 10 unfed Gonyaulax polygramma cells for each feeding mechanism (i.e. horn and sulcus) under a compound microscope at a magnification of 100 to 400 , the time for an $A$. carterae cell to be completely engulfed by $G$. polygramma after the prey cell was contacted by the predator was measured.

Effects of the prey concentration. Expt 5 was designed to investigate the effects of prey concentration on the growth and ingestion rate of Gonyaulax polygramma. We measured growth, ingestion, and clearance rates of $G$. polygramma on an unidentified cryptophyte species $(\mathrm{ESD}=5.6 \mu \mathrm{m}$; carbon content per cell $=$ $0.017 \mathrm{ng} \mathrm{C} C_{i}$ Strathmann 1967) as a function of prey concentration.

A dense culture of Gonyaulax polygramma maintained in $\mathrm{f} / 2$ medium and growing photosynthetically under a 14:10 h light:dark cycle of $50 \mu \mathrm{E} \mathrm{m} \mathrm{m}^{-2} \mathrm{~s}^{-1}$ for $2 \mathrm{wk}$ was transferred into a $1 \mathrm{l}$ PC bottle. Three $1 \mathrm{ml}$ aliquots from the bottle were counted using a compound microscope to determine the cell concentrations of G. polygramma, and the cultures were then used to conduct experiments.

The initial concentrations of Gonyaulax polygramma and a cryptophyte were established using an autopipette to deliver predetermined volumes of known cell concentrations to the bottles. Triplicate $80 \mathrm{ml} \mathrm{PC}$ experimental bottles (containing mixtures of predator and prey) and triplicate prey control bottles (containing prey only) were set up for each predator-prey combination. Triplicate predator control bottles (containing predator only) were also established at 1 predator concentration. Twenty $\mathrm{ml}$ of $\mathrm{f} / 2$ medium were added to all bottles, which were then filled to capacity with freshly filtered seawater and capped. To determine the actual predator and prey densities (cells $\mathrm{ml}^{-1}$ ) at the beginning of the experiment (G. polygramma/cryptophyte $=5 / 18,13 / 46,21 / 94$, 66/189，116/742，518/2020，1057/10259，1879/58272, 505/0) and after 24, 48, and $72 \mathrm{~h}$ incubation, $6 \mathrm{ml}$ aliquots were removed from each bottle and fixed 
with 5\% Lugol's solution, and all G. polygramma cells and all or $>300$ prey cells in $31 \mathrm{ml}$ SedgwickRafter counting chambers were enumerated. Prior to taking subsamples, the condition of G. polygramma and its prey was assessed under a dissecting microscope. The bottles were filled again to capacity with f/2 medium, capped, placed on a vertically rotating plate at $0.9 \mathrm{rpm}$, and incubated at $20^{\circ} \mathrm{C}$ under a 14:10 h light:dark cycle of $50 \mu \mathrm{E} \mathrm{m}^{-2} \mathrm{~s}^{-1}$ of cool white fluorescent light. The dilution of the cultures associated with refilling the bottles was taken into consideration in calculating growth and ingestion rates.

The specific growth rate of Gonyaulax polygramma $\left(\mu, \mathrm{d}^{-1}\right)$, was calculated by averaging the instantaneous growth rates (IGR) for each sampling interval, calculated as:

$$
\mathrm{IGR}=\frac{\ln \left(S_{t_{2}} / S_{t_{1}}\right)}{t_{2}-t_{1}} \times 24
$$

where $S_{t_{1}}$ and $S_{t_{2}}$ are the concentration of G. polygramma at consecutive samplings. The final time $\left(t_{2}\right)$ for the calculation was $48 \mathrm{~h}$, which provided the highest specific growth rate. Mean prey concentrations for $48 \mathrm{~h}$ were also calculated by averaging the instantaneous mean prey concentrations at 0 to $24 \mathrm{~h}$ and 24 to $48 \mathrm{~h}$. The instantaneous mean prey concentration for each sampling interval was calculated using the equations of Frost (1972).

Data for Gonyaulax polygramma growth rate were fitted to a Michaelis-Menten equation:

$$
\mu=\frac{\mu_{\max }\left(x-x^{\prime}\right)}{K_{\mathrm{GR}}+\left(x-x^{\prime}\right)}
$$

where $\mu_{\max }$ is the maximum growth rate $\left(\mathrm{d}^{-1}\right) ; x$ is the prey concentration (cells $\mathrm{ml}^{-1}$ or $\mathrm{ng} \mathrm{C} \mathrm{ml} \mathrm{Cl}^{-1}$ ); $\mathrm{x}^{\prime}$ is the threshold prey concentration (the prey concentration where $\mu=0$ ), and $K_{\mathrm{GR}}$ is the prey concentration sustaining $1 / 2 \mu_{\text {max }}$. Data were iteratively fitted to the model using DeltaGraph ${ }^{\circledR}$ (SPSS).

Ingestion and clearance rates for $48 \mathrm{~h}$ were also calculated using the equations of Frost (1972) and Heinbokel (1978). Ingestion rate data were fitted to a Michaelis-Menten equation:

$$
\mathrm{IR}=\frac{I_{\max }}{K_{\mathrm{IR}}+(x)}
$$

where $I_{\max }$ is the maximum ingestion rate (cells predator $^{-1} \mathrm{~d}^{-1}$ or ng $\mathrm{C}$ predator ${ }^{-1} \mathrm{~d}^{-1}$ ); $\mathrm{x}$ is the prey concentration (cells ml ${ }^{-1}$ or $\mathrm{ng} \mathrm{C} \mathrm{ml}^{-1}$ ); and $K_{\mathrm{IR}}$ is the prey concentration sustaining $1 / 2 I_{\max }$.

Grazing impact. We estimated the grazing coefficients attributable to Gonyaulax polygramma on cryptophytes by combining field data on abundances of the grazer and the prey with ingestion rates of the grazer on the prey obtained in the present study (see Table 2).
Data on the abundances of G. polygramma and cooccurring cryptophytes used in this estimation were obtained from the water samples taken off Kwangyang (in 1999-2000), Saemankeum (in 1999-2002), and Tongyoung (in 2004), Korea.

The grazing coefficients $\left(g, \mathrm{~h}^{-1}\right)$ were calculated as:

$$
g=(1 / \Delta t)\left\{\ln \left[C_{\mathrm{i}} /\left(C_{\mathrm{i}}-C_{\mathrm{e}}\right)\right]\right\}
$$

where $\Delta t(\mathrm{~h})$ is time interval, $C_{\mathrm{e}}\left(\right.$ cells $\mathrm{ml}^{-1}$ ) is the number of prey cells eaten by the Gonyaulax polygramma population in $1 \mathrm{ml}$ of seawater in $1 \mathrm{~h}$, and $C_{\mathrm{i}}\left(\right.$ cells ml $\left.\mathrm{m}^{-1}\right)$ is the initial prey cell concentration at a given hour. The values of $C_{\mathrm{e}}$ were calculated as:

$$
C_{\mathrm{e}}=\mathrm{PIR} \times 1 \mathrm{~h}=\mathrm{IR} \times G \times 1 \mathrm{~h}
$$

where PIR is the population ingestion rate of G. polygramma on a cryptophyte in $1 \mathrm{ml}$ of seawater (prey eaten $\mathrm{ml}^{-1} \mathrm{~h}^{-1}$ ), IR is the ingestion rate (prey eaten $G$. polygramma ${ }^{-1} \mathrm{~h}^{-1}$ ) of $G$. polygramma on a cryptophyte, and $G$ is the initial abundance (cells $\mathrm{ml}^{-1}$ ) of $G$. polygramma at the same time as $C_{\mathrm{i}}$.

\section{RESULTS}

\section{Prey species}

Among the phytoplankton prey offered, Gonyaulax polygramma ingested the small phytoplankton species (the prymnesiophyte Isochrysis galbana, an unidentified cryptophyte, the raphidophyte Heterosigma akashiwo, the dinoflagellates Amphidinium carterae, Heterocapsa triquetra, Prorocentrum minimum, and Scrippsiella sp.; Fig. 1) with ESDs $\leq 17 \mu \mathrm{m}$, but it did not feed on the large phytoplankton species (the dinoflagellates Akashiwo sanguinea, Alexandrium tamarense, Cochlodinium polykrikoides, Gymnodinium catenatum, Lingulodinium polyedrum, and P. micans) with ESDs $>22 \mu \mathrm{m}$ (Table 1).

\section{Feeding frequency}

After 10 min incubation, the feeding frequencies (FFs) of Gonyaulax polygramma on Isochrysis galbana, a cryptophyte, Amphidinium carterae, and Heterosigma akashiwo (86 to $97 \%$ ) were much higher than those on Heterocapsa triquetra, Prorocentrum minimum, and Scrippsiella sp. (3 to $34 \%$ ) (Fig. 2). With increasing elapsed incubation time, FFs of G. polygramma on H. triquetra, P. minimum, and Scrippsiella sp. linearly increased. However, after $60 \mathrm{~min}$ incubation, FF on Scrippsiella sp. was still only $9 \%$, while FF of $G$. polygramma on $H$. triquetra and $P$. minimum had become 87 to $88 \%$. 
Table 1. Taxa, sizes, and concentration of Gonyaulax polygramma and phytoplankton species offered as food to G. polygramma in Expts 1 to 4 . To confirm no ingestion by G. polygramma on some phytoplankton species, additional higher prey concentrations were provided. Y: G. polygramma was observed to contain food cells in the protoplasm; N: G. polygramma was observed not to contain food cells. Mean equivalent spherical diameter $(\mathrm{ESD}, \mu \mathrm{m}) \pm$ standard deviation of the mean was measured by an electronic particle counter (Coulter Multisizer II, Coulter Corporation). n > 2000 for each species. *PRY: Prymnesiophyceae; CRP: Cryptophyceae; RAP: Raphidophyceae; DIN: Dinophyceae

\begin{tabular}{|c|c|c|c|}
\hline Species & $\mathrm{ESD}( \pm \mathrm{SD})$ & $\begin{array}{l}\text { Initial prey } \\
\text { concentration } \\
\left(\text { cells ml }{ }^{-1}\right)\end{array}$ & Feeding \\
\hline Isochrysis galbana ( $\left.{ }^{*} \mathrm{PRY}\right)$ & $4.8(0.2)$ & 100000 & $\mathrm{Y}$ \\
\hline Cryptophyte (CRP) & $5.6(1.5)$ & 50000 & $\mathrm{Y}$ \\
\hline Amphidinium carterae (DIN) & $6.6(1.5)$ & 33000 & $\mathrm{Y}$ \\
\hline Heterosigma akashiwo (RAP) & $11.0(0.4)$ & 10000 & $\mathrm{Y}$ \\
\hline Heterocapsa triquetra (DIN) & $12.7(0.6)$ & 6200 & $\mathrm{Y}$ \\
\hline Prorocentrum minimum (DIN) & $12.9(3.6)$ & 6000 & $\mathrm{Y}$ \\
\hline Scrippsiella sp. (DIN) & $17.0(5.9)$ & 1500 & $\mathrm{Y}$ \\
\hline Cochlodinium polykrikoides (DIN) & $23.1(3.2)$ & $1500-4000$ & $\mathrm{~N}$ \\
\hline Alexandrium tamarense (DIN) & $24.8(1.0)$ & $1200-4000$ & $\mathrm{~N}$ \\
\hline Prorocentrum micans (DIN) & $26.0(2.3)$ & $1000-3000$ & $\mathrm{~N}$ \\
\hline Gymnodinium catenatum (DIN) & $33.9(1.6)$ & $500-2000$ & $\mathrm{~N}$ \\
\hline Akashiwo sanguinea (DIN) & $36.3(5.6)$ & $400-1500$ & $\mathrm{~N}$ \\
\hline Lingulodinium polyedrum (DIN) & $37.9(4.5)$ & $400-1500$ & $\mathrm{~N}$ \\
\hline Gonyaulax polygramma (DIN) ${ }^{\mathrm{a}}$ & $32.5(5.4)$ & & \\
\hline
\end{tabular}

\section{Feeding mechanisms}

Gonyaulax polygramma fed on phytoplankton cells by engulfing the prey through both the apical horn and the sulcus (Fig. 3). When unialgal diets of phytoplankton species were provided, the ratios of the frequencies of engulfment through the apical horn and the sulcus of Gonyaulax polygramma were 83:17 ( $\mathrm{n}=229$ ) for the cryptophyte, 48:52 (n = 90) for Amphidinium carterae, 12:88 ( $\mathrm{n}=66$ ) for Heterosigma akashiwo, 5:95 ( $\mathrm{n}=77)$ for Heterocapsa triquetra, and 1:99 (n=75) for Prorocentrum minimum prey (Fig. 4). G. polygramma fed on Scrippsiella sp. cells by engulfing the prey through only the sulcus $(\mathrm{n}=126)$.

The time for an Amphidinium carterae cell to be completely engulfed through the apical horn of Gonyaulax polygramma after the prey cell was contacted by the predator (mean \pm SD, $291 \pm 73 \mathrm{~s}$ ) was not significantly higher than for through the sulcus of the predator (346 $\pm 79 \mathrm{~s})$ (1-tailed $t$-test, $0.1>\mathrm{p}>0.05)$.
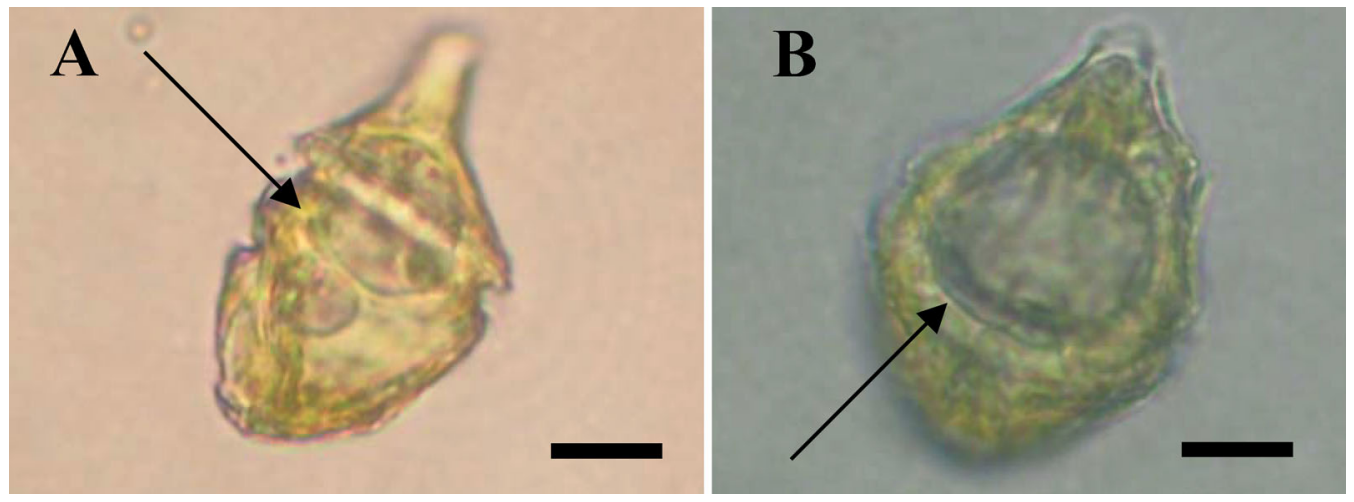

Fig. 1. Gonyaulax polygramma with ingested (A) Heterocapsa triquetra and (B) Scrippsiella sp. cell. Arrows indicate ingested prey cells. Scale bars $=10 \mu \mathrm{m}$
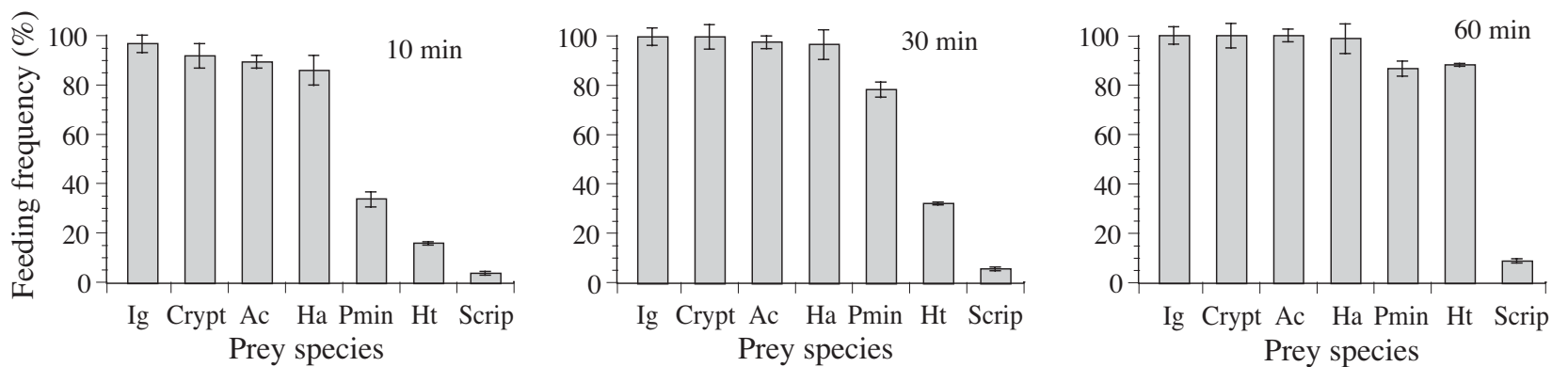

Fig. 2. Gonyaulax polygramma. Feeding frequency on Isochrysis galbana (Ig), a cryptophyte (Crypt), Amphidinium carterae (Ac), Heterosigma akashiwo (Ha), Prorocentrum minimum (Pmin), Heterocapsa triquetra (Ht), and Scrippsiella sp. (Scrip) at 3 different elapsed incubation times $(10,30$, and $60 \mathrm{~min})$; the proportion of the G. polygramma cells observed to contain prey, measured by calculating the percent ratio of G. polygramma containing 1 or more target prey cells to total G. polygramma. Treatment means \pm SD are shown 

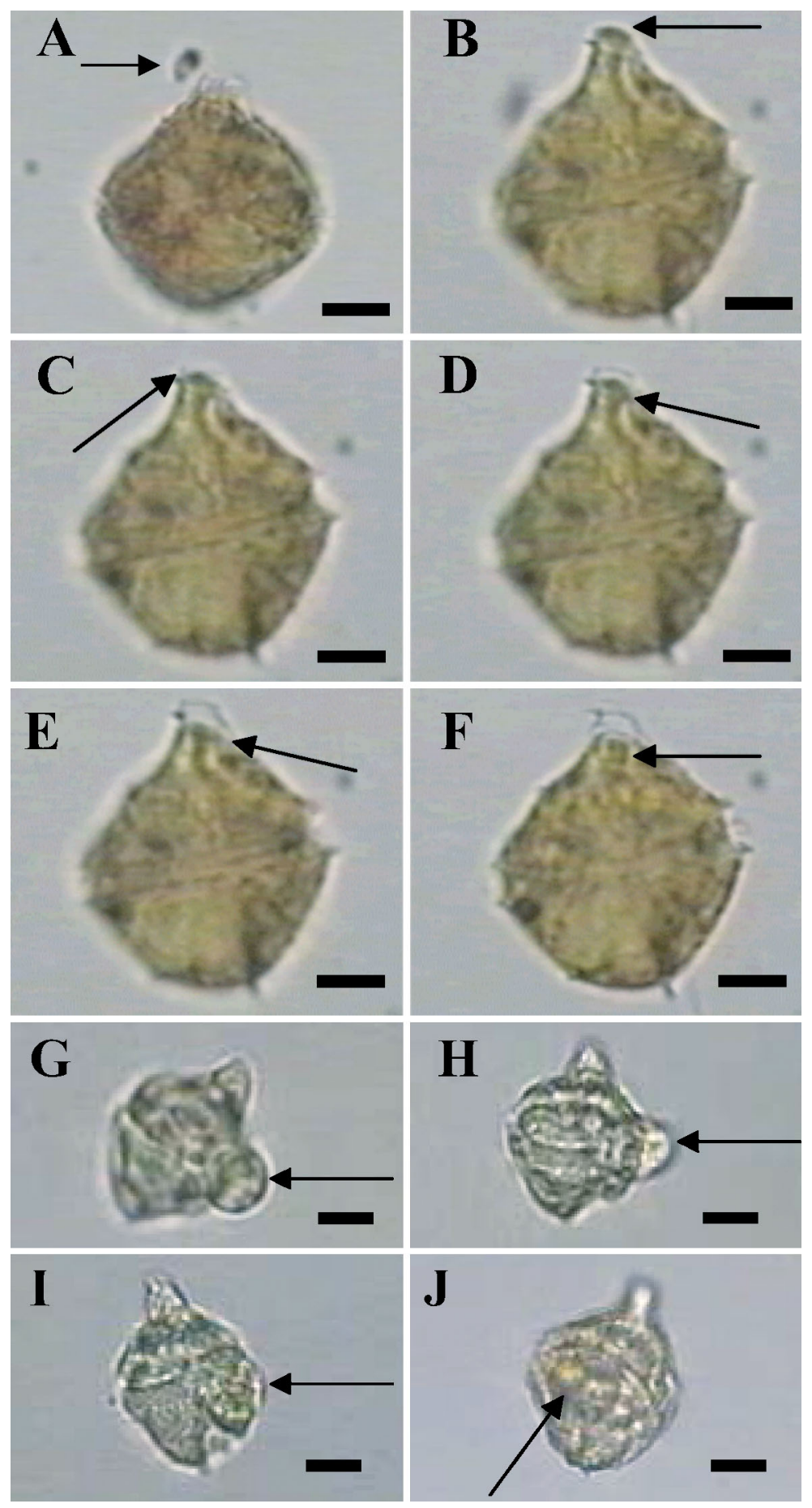

Fig. 3. (A-F) Gonyaulax polygramma engulfing a cryptophyte cell through the apical horn. Pictures were taken in sequence using a video analyzing system on a compound microscope. (A) G. polygramma and a freely swimming cryptophyte, (B) G. polygramma capturing a cryptophyte cell by the apical horn, (C-E) a cryptophyte cell passing through the apical horn of G. polygramma, $(\mathrm{F})$ an ingested cryptophyte cell beneath the horn. Predator and prey cells in $(B-F)$ were the same predator and prey cells, respectively. $(\mathrm{G}-\mathrm{J})$ G. polygramma engulfing a Prorocentrum minimum cell through the sulcus. $(\mathrm{G}, \mathrm{H})$ a $P$. minimum cell passing through the sulcus of $G$. polygramma, $(\mathrm{I}, \mathrm{J})$ an ingested $P$. minimum cell through the sulcus. Predator and prey cells in $(\mathrm{G}-\mathrm{J})$ were the same predator and prey cells, respectively. Arrows indicate prey cells. Scale bars $=10 \mu \mathrm{m}$

\section{Effects of prey concentration}

The specific growth rates of Gonyaulax polygramma on a cryptophyte increased with increasing mean prey concentration, with saturation at a mean prey concentration of approximately $600 \mathrm{ng} \mathrm{C} \mathrm{ml}^{-1}$ (i.e. 35300 cells $\mathrm{ml}^{-1}$ ) (Fig. 5). When the data were fitted to Eq. (2), the maximum specific growth rate of G. polygramma on a cryptophyte (mixotrophic growth) was $0.278 \mathrm{~d}^{-1}$, under a 14:10 h light:dark cycle of $50 \mu \mathrm{E} \mathrm{m} \mathrm{m}^{-2} \mathrm{~s}^{-1}$, while its growth rate under the same light conditions without added prey (phototrophic growth) was only $0.186 \mathrm{~d}^{-1}$.

Ingestion rates of Gonyaulax polygramma feeding on a unialgal diet of a cryptophyte increased continuously with increasing mean prey concentration offered in the present study (Fig. 6). When the data were fitted to Eq. (3), the maximum ingestion rate of G. polygramma on a cryptophyte was 0.18 ng $C$ grazer ${ }^{-1} \mathrm{~d}^{-1}$ (10.6 cells grazer ${ }^{-1}$ $\left.\mathrm{d}^{-1}\right)$. The maximum clearance rate of $G$. polygramma on a cryptophyte was $0.18 \mu \mathrm{l}$ grazer $^{-1} \mathrm{~h}^{-1}$.

\section{Grazing impact}

Grazing coefficients $(g)$ attributable to Gonyaulax polygramma on co-occurring cryptophytes in the coastal waters off Kwangyang (in 1999-2000), Saemankeum (in 1999-2002), and Tongyoung (in 2004), Korea were up to $0.479 \mathrm{~h}^{-1}$ (Table 2, Fig. 7). In general, grazing coefficients increased with increasing G. polygramma concentration.

\section{DISCUSSION}

\section{Prey species}

Among the phytoplankton species offered in the present study, Gonyaulax polygramma was able to feed on phytoplankton belonging to diverse classes such as Prymnesiophyceae (Isochrysis galbana), Cryptophyceae, Raphidophyceae (Heterosigma akashiwo), Dinophyceae (Amphidinium carterae, Heterocapsa triquetra and Prorocentrum minimum). All the phytoplankton 


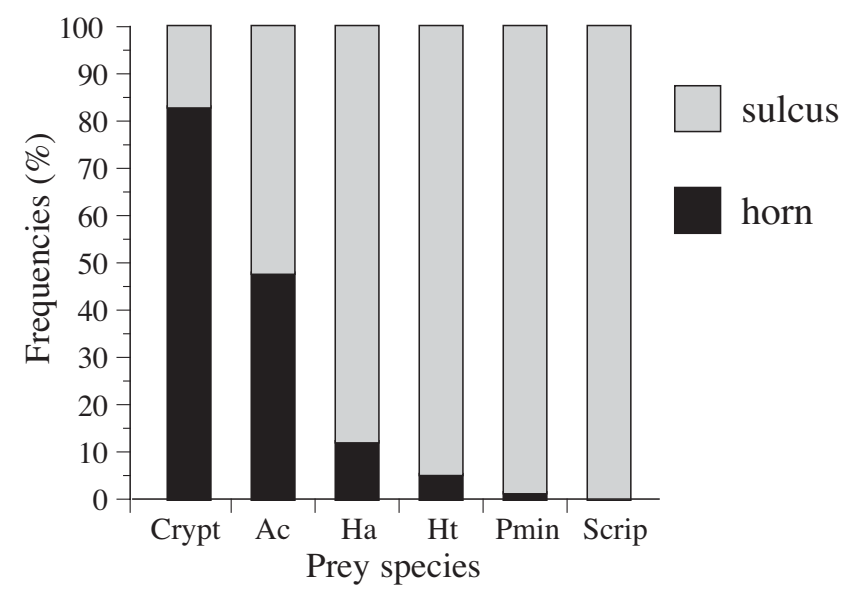

Fig. 4. Gonyaulax polygramma. Frequencies of engulfment through the apical horn and the sulcus when feeding on unialgal diets of a cryptophyte (Crypt, $\mathrm{n}=229$ ), Amphidinium carterae (Ac, $\mathrm{n}=90)$, Heterosigma akashiwo $(\mathrm{Ha}, \mathrm{n}=66)$, Heterocapsa triquetra $(\mathrm{Ht}, \mathrm{n}=77)$, Prorocentrum minimum (Pmin, $\mathrm{n}=75)$, and Scrippsiella sp. (Scrip, $\mathrm{n}=126)$

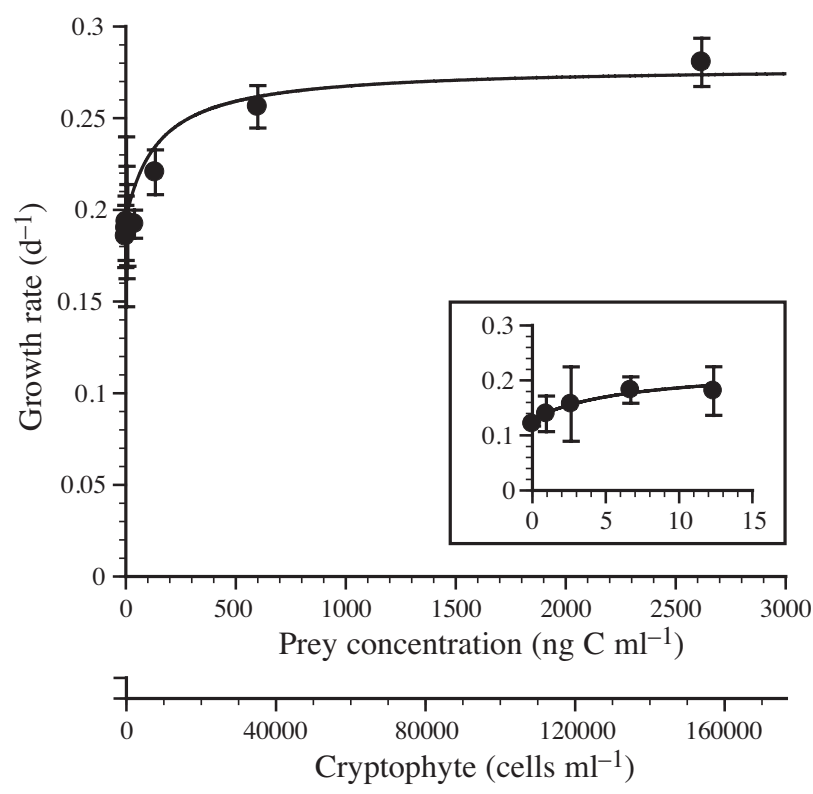

Fig. 5. Gonyaulax polygramma. Specific growth rates on an unidentified cryptophyte as a function of mean prey concentration. Symbols represent treatment means \pm 1 SE. Curves were fitted by a Michaelis-Menten equation (Eq. 2) using all treatments in the experiment. Growth rate $\left(\mathrm{GR}, \mathrm{d}^{-1}\right)=0.278$ $\{(x+98) /[44+(x+98)]\}, r^{2}=0.47$. Inset shows values at low prey concentrations

species ingested by G. polygramma had ESDs $\leq 17 \mu \mathrm{m}$, while the species not ingested by G. polygramma had ESDs $>22 \mu \mathrm{m}$. Therefore, whether or not G. polygramma is able to ingest a phytoplankton species appears to be mainly affected by the size of the prey species.

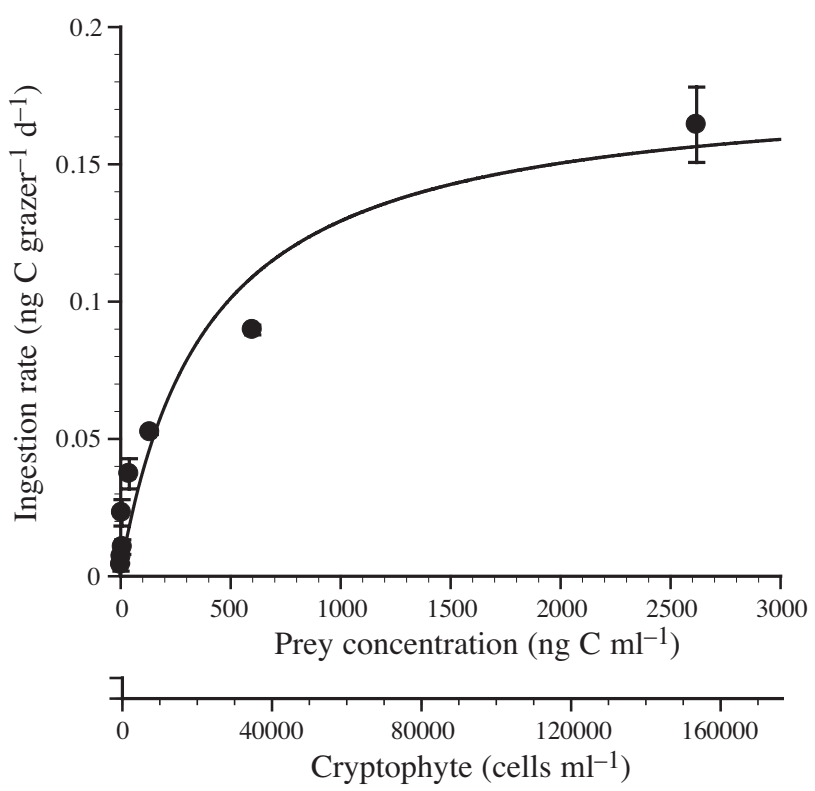

Fig. 6. Gonyaulax polygramma. Ingestion rate on an unidentified cryptophyte as a function of mean prey concentration. Symbols represent treatment means \pm 1 SE. Curves were fitted by a Michaelis-Menten equation (Eq. 3) using all treatments in the experiment. Ingestion rate $\left(\mathrm{IR}, \mathrm{ng} \mathrm{C}\right.$ grazer $\left.^{-1} \mathrm{~d}^{-1}\right)=$ $0.18[x /(393+x)], r^{2}=0.919$

\section{Feeding frequency}

FFs of Gonyaulax polygramma on the smaller prey species such as Isochrysis galbana, a cryptophyte, Amphidinium carterae, and Heterosigma akashiwo after 10 min incubation (86 to $97 \%$ ) were much higher than those on the larger prey species such as Heterocapsa triquetra, Prorocentrum minimum, and Scrippsiella sp. (3 to $34 \%$ ). The strain of $A$. carterae used in the present study is known to be toxic (Jeong et al. 2001), but the FF of G. polygramma on this species was similar to that on the non-toxic algal cryptophyte or H. akashiwo. Therefore, the FF appears to be mainly affected by prey size. However, there is still a possibility that the FFs for smaller prey species might have been overestimated compared to larger prey species due to a higher encounter rate for the former species than the latter because the concentrations of the smaller prey species were higher than those for the larger prey species even though their carbon biomasses were similar.

\section{Feeding mechanisms}

Gonyaulax polygramma fed on phytoplankton cells by engulfing the prey through both the apical horn and the sulcus. So far, engulfment-feeding mixotrophic and heterotrophic dinoflagellates have only been known 
Table 2. Estimation of grazing impact by a Gonyaulax polygramma population on cryptophyte populations using the equation for ingestion rate in Fig. 6 legend, and the abundances of co-occurring cryptophytes and G. polygramma obtained from the water samples collected off Kwangyang (in 1999-2000), Saemankeum (in 1999-2002), and Tongyoung (in 2004), Korea. GpIR: G. polygramma's population ingestion rate; Gpg: G. polygramma's grazing coefficient $\left(\mathrm{h}^{-1}\right)$

\begin{tabular}{|c|c|c|c|}
\hline $\begin{array}{l}\text { Cryptophyte } \\
\text { concentration } \\
\left(\text { cells } \mathrm{ml}^{-1}\right)\end{array}$ & $\begin{array}{l}\text { G. polygramma } \\
\text { concentration } \\
\text { (cells ml }{ }^{-1} \text { ) }\end{array}$ & $\begin{array}{c}\text { GpIR } \\
\text { (prey eaten } \\
\mathrm{ml}^{-1} \mathrm{~h}^{-1} \text { ) }\end{array}$ & $\begin{array}{c}\text { Gpg } \\
\left(\mathrm{h}^{-1}\right)\end{array}$ \\
\hline 75 & 20000 & 29 & 0.479 \\
\hline 350 & 1005 & 7 & 0.019 \\
\hline 390 & 3920 & 29 & 0.076 \\
\hline 440 & 1620 & 13 & 0.031 \\
\hline 580 & 900 & 10 & 0.017 \\
\hline 710 & 1810 & 24 & 0.034 \\
\hline 800 & 118 & 2 & 0.002 \\
\hline 1595 & 105 & 3 & 0.002 \\
\hline 3550 & 123 & 7 & 0.002 \\
\hline
\end{tabular}

to engulf a prey cell through the sulcus (Schnepf \& Elbrächter 1992, Skovgaard 1996, Jeong et al. 1997, 1999, Hansen \& Calado 1999). Therefore, this study is the first report of engulfment feeding through the apical horn of dinoflagellates.

The ratios of the frequencies of engulfment through the apical horn and the sulcus of Gonyaulax polygramma on a cryptophyte $(83: 17, \mathrm{ESD}=5.6 \mu \mathrm{m})$ and Amphidinium carterae (48:52, $\mathrm{ESD}=6.6 \mu \mathrm{m})$ were much higher than those for Heterosigma akashiwo

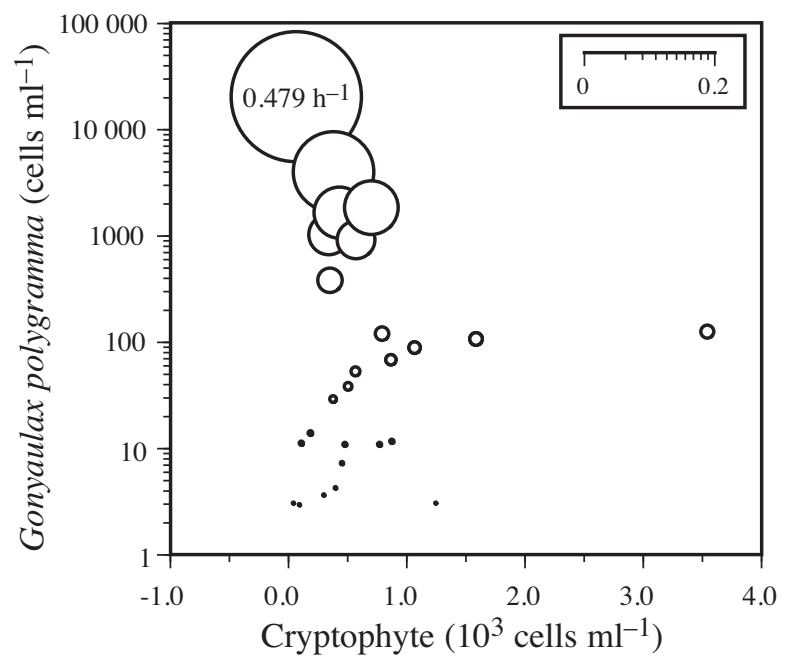

Fig. 7. Gonyaulax polygramma. Calculated grazing coefficients $(g)$ in relation to the concentration of co-occurring cryptophytes (see text for calculation). $\mathrm{N}=37$. The scale of the circles in the inset box is $g\left(\mathrm{~h}^{-1}\right)$. A value of $g$ was $0.479 \mathrm{~h}^{-1}$ when the concentrations of cryptophytes and G. polygramma were 75 and 20000 cells ml ${ }^{-1}$, respectively. The scale for this $g$ has been reduced
$(12: 88, \mathrm{ESD}=11.0 \mu \mathrm{m})$, Heterocapsa triquetra $(5: 95$, $12.6 \mu \mathrm{m})$, Prorocentrum minimum (1:99, $12.9 \mu \mathrm{m})$, or Scrippsiella sp. (0:100, $17.0 \mu \mathrm{m})$. G. polygramma may prefer to engulf a small prey species through the apical horn and a large prey species through the sulcus. Therefore, whether G. polygramma uses the apical horn or the sulcus for engulfment may be affected by prey size.

\section{Effects of prey concentration}

Both growth and ingestion rates of Gonyaulax polygramma feeding on a unialgal diet of a cryptophyte were affected by the prey concentration. A unialgal diet of a cryptophyte can support a population growth of G. polygramma (mixotrophic growth, $0.278 \mathrm{~d}^{-1}$ ) $49 \%$ higher than that without added prey (phototrophic growth, $0.186 \mathrm{~d}^{-1}$ ) under the conditions provided in the present study. This evidence suggests that G. polygramma may be able to increase or maintain its population by feeding on cryptophytes under conditions which are less favorable for phototrophic growth if prey is abundant.

The maximum ingestion and clearance rates of Gonyaulax polygramma feeding on a unialgal diet of a cryptophyte under the conditions provided in the present study (10.6 cells grazer ${ }^{-1} \mathrm{~d}^{-1}$ and $0.18 \mu$ grazer $^{-1}$ $\mathrm{h}^{-1}$, respectively) were comparable to those of Cochlodinium polykrikoides on the same prey (9.4 cells grazer $^{-1} \mathrm{~d}^{-1}$ and $0.33 \mu \mathrm{l}$ grazer $^{-1} \mathrm{~h}^{-1}$, respectively) obtained under a 14:10 h light:dark cycle of $50 \mu \mathrm{E} \mathrm{m} \mathrm{m}^{-2}$ $\mathrm{s}^{-1}$ (Jeong et al. 2004). Therefore, G. polygramma may compete with $C$. polykrikoides for a cryptophyte prey if they co-occur.

\section{Grazing impact}

Grazing coefficients $(g)$ attributable to Gonyaulax polygramma on co-occurring cryptophytes obtained in the present study were up to $0.479 \mathrm{~h}^{-1}$ (i.e. up to $38 \%$ of cryptophyte populations were removed by a $G$. polygramma population in $1 \mathrm{~h}$ ). The results of the present study suggest that G. polygramma may sometimes have a considerable grazing impact on populations of co-occurring cryptophytes. The grazing rates of some mixotrophic dinoflagellates are known to be affected by light and/or nutrient conditions (Hansen \& Nielsen 1997, Stoecker et al. 1997, Jeong et al. 1999, Li et al. 2000, Hansen et al. 2000, Jakobsen et al. 2000, Skovgaard et al. 2000). Therefore, the grazing impact of $G$. polygramma on co-occurring cryptophytes may also be affected by light and/or nutrient conditions. 
Acknowledgements. We thank Dr. Jae Seong Kim, Tae Hoon Kim, Seong Taek Kim, and Jae Yoon Song for technical supports. This paper was funded by a National Research Laboratory grant from the Korea Science and Engineering Foundation (M1-0302-00-0068).

\section{LITERATURE CITED}

Bockstahler KR, Coats DW (1993) Grazing of the mixotrophic dinoflagellate Gymnodinium sanguineum on ciliate populations of Chesapeake Bay. Mar Biol 116:447-487

ECOHAB (1995) The ecology and oceanography of harmful algal blooms. A national research agenda. Woods Hole Oceanographic Institute, Woods Hole, p 1-66

Faust MA (2000) Biodiversity of planktonic dinoflagellate species in mangrove ponds, Pelican Cays, Belize. J Phycol 36(Suppl):22

Frost BW (1972) Effects of size and concentration of food particles on the feeding behavior of the marine planktonic copepod Calanus pacificus. Limnol Oceanogr 17:805-815

Garate-Lizarraga I, Hernandez Orozco ML, Band Schmidt ChJ, Serrano Casillas G (2001) Red tides along the coasts of Baja California Sur, Mexico (1984 to 2001). Invest Mar CICIMAR (Oceanides) 16:127-134

Granéli E, Anderson DM, Carlsson P, Maestrini SY (1997) Light and dark carbon uptake by Dinophysis species in comparison to other photosynthetic and heterotrophic dinoflagellates. Aquat Microb Ecol 13:177-186

Grindley JR, Taylor FJR (1962) Red water and mass-mortality of fish near Cape Town. Nature (Lond) 195:1324

Guillard RRL, Ryther JH (1962) Studies of marine planktonic diatoms. I. Cyclotella nana Hustedt and Detonula confervacea (Cleve) Grun. Can J Microbiol 8:229-239

Hansen PJ, Calado AJ (1999) Phagotrophic mechanisms and prey selection in free-living dinoflagellates. J Eukaryot Microbiol 46:382-389

Hansen PJ, Nielsen TG (1997) Mixotrophic feeding of Fragilidium subglobosum (Dinophyceae) on three species of Ceratium: effects of prey concentration, prey species and light intensity. Mar Ecol Prog Ser 147:187-196

Hansen PJ, Skovgaard A, Glud RN, Stoecker DK (2000) Physiology of the mixotrophic dinoflagellate Fragilidium subglobosum. II. Effects of time scale and prey concentration on photosynthetic performance. Mar Ecol Prog Ser 201:137-146

Heinbokel JF (1978) Studies on the functional role of tintinnids in the Southern California Bight. I. Grazing and growth rates in laboratory cultures. Mar Biol 47:177-189

Jacobson DM, Anderson DM (1996) Widespread phagocytosis of ciliates and other protists by marine mixotrophic and heterotrophic thecate dinoflagellates. J Phycol 32:279-285

Jakobsen HH, Hansen PJ, Larsen J (2000) Growth and grazing responses of two chloroplast-retaining dinoflagellates: effect of irradiance and prey species. Mar Ecol Prog Ser 201:121-128

Jeong HJ, Lee CW, Yih WH, Kim JS (1997) Fragilidium cf. mexicanum, a thecate mixotrophic dinoflagellate, which is prey for and a predator on co-occurring thecate heterotrophic dinoflagellate Protoperidinium cf. divergens. Mar Ecol Prog Ser 151:299-305

Jeong HJ, Shim JH, Kim JS, Park JY, Lee CW, Lee Y (1999) The feeding by the thecate mixotrophic dinoflagellate Fragilidium cf. mexicanum on red tide and toxic dino- flagellate. Mar Ecol Prog Ser 176:263-277

Jeong HJ, Kang HJ, Shim JH, Park JK, Kim JS, Song JY, Choi HJ (2001) Interactions among the toxic dinoflagellate Amphidinium carterae, the heterotrophic dinoflagellate Oxyrrhis marina, and the calanoid copepods Acartia spp. Mar Ecol Prog Ser 218:77-86

Jeong HJ, Yoo YD, Kim JS, Kim TH, Kim JH, Kang NS, Yih WH (2004) Mixotrophy in the phototrophic harmful alga Cochlodinium polykrikoides (Dinophycean): prey species, the effects of prey concentration and grazing impact. J Eukaryot Microbiol 51:563-569

Kamykowski D (1980) Sub-thermocline maximums of the dinoflagellates Gymnodinium simplex (Lohmann) Kofoid and Swezy and Gonyaulax polygramma Stein. Northeast Gulf Sci 4:39-43

Koizumi Y, Kohno J, Matsuyama N, Uchida T, Honjo T (1996) Environmental features and the mass mortality of fish and shellfish during the Gonyaulax polygramma red tide occurred in and around Uwajima Bay, Japan, in 1994. Nippon Suisan Gakkaishi 62:217-224

Koizumi Y, Ichikawa M, Tamura S, Nagatomo M, Uchida Takuji (2001) Diurnal vertical migration of Gonyaulax polygramma stein (Dinopyceae) during a red tide in Shibata Bay, Ehime, Japan. Bull Jpn Soc Fish Oceanogr 65: 131-134

Lam CWY, Yip SSY (1990) A three-month red tide event in Hong Kong. In: Granéli E, Sundstroem B, Edler L, Anderson DM (eds) Toxic marine phytoplankton. Elsevier, New York, p 481-486

Li A, Stoecker DK, Coats DW (2000) Mixotrophy in Gyrodinium galatheanum (Dinophyceae): grazing responses to light intensity and inorganic nutrients. J Phycol 36:33-45

Lin Y, Zhou J, Li A (1993) An ecological study on the occurrence of the tide of Gonyaulax polygramma in Yantian waters, Dapeng Bay. Trop Oceanol/Redai Haiyang 12: $46-50$

Ounissi M, Retima A (2001) Nutritive salts and organic matter variability in Melah Lagoon (Algeria). Importance of seaexchanges. J Rech Oceanogr 26:45

Schnepf E, Elbrächter M (1992) Nutritional strategies in dinoflagellates: a review with emphasis on cell biological aspects. Eur J Protistol 28:3-24

Skovgaard A (1996) Engulfment of Ceratium spp. (Dinophyceae) by the thecate photosynthetic dinoflagellate Fragilidium subglobosum. Phycologia 35:490-499

Skovgaard A (2000) A phagotrophically derivable growth factor in the plastidic dinoflagellate Gyrodinium resplendens (Dinophyceae). J Phycol 36:1069-1078

Skovgaard A, Hansen PJ, Stoecker DK (2000) Physiology of the mixotrophic dinoflagellate Fragilidium subglobosum. I. Effects of phagotrophy and irradiance on photosynthesis and carbon content. Mar Ecol Prog Ser 201:129-136

Smalley GW, Coats DW, Adam EJ (1999) A new method using fluorescent microspheres to determine grazing on ciliates by the mixotrophic dinoflagellate Ceratium furca. Aquat Microb Ecol 17:167-179

Stoecker DK (1999) Mixotrophy among dinoflagellates. J Eukaryot Microbiol 46:397-401

Stoecker DK, Li A, Coats DW, Gustafson DE, Nannen MK (1997) Mixotrophy in the dinoflagellate Prorocentrum minimum. Mar Ecol Prog Ser 152:1-12

Strathmann RR (1967) Estimating the organic carbon content of phytoplankton from cell volume or plasma volume. Limnol Oceanogr 12:411-418

Submitted: April 25, 2004; Accepted: December 2, 2004

Proofs received from author(s): February 11, 2005 